\title{
The Current Incidence of Viral Disease in Korean Sweet Potatoes and Development of Multiplex RT-PCR Assays for Simultaneous Detection of Eight Sweet Potato Viruses
}

\author{
Hae-Ryun Kwak ${ }^{1}$, Mi-Kyeong Kim ${ }^{1}$, Jun-Chul Shin ${ }^{1}$, Ye-Ji Lee, Jang-Kyun Seo ${ }^{1}$,Hyeong-Un Lee ${ }^{2}$, Mi-Nam Jung ${ }^{2}$, \\ Sun-Hyung $\mathrm{Kim}^{3}$ and Hong-Soo Choi ${ }^{\text {* }}$ \\ ${ }^{1}$ Crop Protection Division, National Academy of Agricultural Science, Wanju 565-851, Korea \\ ${ }^{2}$ Bioenergy Crop Research Center, National Institute of Crop Science, Muan 534-833, Korea \\ ${ }^{3}$ Department of Environmental Horticulture, University of Seoul, Seoul 130-743, Korea
}

(Received on April 1, 2014; Revised on August 20, 2014; Accepted on September 16, 2014)

Sweet potato is grown extensively from tropical to temperate regions and is an important food crop worldwide. In this study, we established detection methods for 17 major sweet potato viruses using single and multiplex RT-PCR assays. To investigate the current incidence of viral diseases, we collected 154 samples of various sweet potato cultivars showing virus-like symptoms from 40 fields in 10 Korean regions, and analyzed them by RT-PCR using specific primers for each of the 17 viruses. Of the 17 possible viruses, we detected eight in our samples. Sweet potato feathery mottle virus (SPFMV) and sweet potato virus C (SPVC) were most commonly detected, infecting approximately $87 \%$ and $85 \%$ of samples, respectively. Furthermore, Sweet potato symptomless virus 1 (SPSMV-1), Sweet potato virus G (SPVG), Sweet potato leaf curl virus (SPLCV), Sweet potato virus 2 ( SPV2), Sweet potato chlorotic fleck virus (SPCFV), and Sweet potato latent virus (SPLV) were detected in $67 \%, 58 \%, 47 \%, 41 \%, 31 \%$, and $20 \%$ of samples, respectively. This study presents the first documented occurrence of four viruses (SPVC, SPV2, SPCFV, and SPSMV-1) in Korea. Based on the results of our survey, we developed multiplex RT-PCR assays for simple and simultaneous detection of the eight sweet potato viruses we recorded.

Keywords : disease incidence, sweet potato viruses, multiplex RT-PCR

\footnotetext{
*Corresponding author.

Phone) +82-63-238-3301, FAX) +82-63-238-3838

E-mail)hschoi@korea.kr
}

Sweet potato (Ipomea batatas L.), of the family Convolvulaceae, is grown extensively from tropical to temperate regions and is an important food crop worldwide. According to FAOSTAT data, there are 8 million ha of sweet potato in cultivation worldwide, with approximately 103 million metric tons produced in 2012. Major sweet potato-producing nations include China, Tanzania, Nigeria, Uganda, and Indonesia; production in China alone is around 73 million metric tons, or more than $70 \%$ of the worldwide total. Korea currently produces approximately 260,000 metric tons from 19,000 ha, with production increasing every year.

Viral diseases of sweet potato have become widespread, causing serious crop losses around the world. In total, more than 30 viruses have now been reported to infect sweet potato (Brunt et al., 1996; Clark et al., 2012). Among these, 23 have been assigned a formal taxonomic position by the International Committee on Taxonomy of Viruses (ICTV) (Table 1). The number continues to increase as virus detection methods are improved. Only a few of the viruses are considered to be of major economic importance. The most severe disease in sweet potato is caused by coinfection with the whitefly-transmitted Sweet potato chlorotic stunt virus (SPCSV) and the aphid-transmitted Sweet potato feathery mottle virus (SPFMV), which results in the synergistic sweet potato virus disease (SPVD) (Gibson et al., 1998; Karyeija et al., 2000; Mukasa et al., 2006). Synergism has also been observed between SPCSV and the possibly whitefly-transmitted Sweet potato mild mottle virus (SPMMV) (Gutiérrez et al., 2003; Hahn, 1979). SPCSV caused synergistic diseases in sweet potato with many other sweet potato viruses (Untiveros et al., 2007).

In Korea, SPFMV, Sweet potato virus G (SPVG), and Sweet potato latent virus (SPLV), all belonging to the family Potyviridae, and Sweet potato leaf curl virus (SPLCV), a member of the Geminiviridae, have been detected (Kwak 
Table 1. Major viruses infecting sweet potato

\begin{tabular}{lllc}
\hline \multicolumn{1}{c}{ Virus name } & \multicolumn{1}{c}{ Abb. } & \multicolumn{1}{c}{ Family (genus) } & Transmission \\
\hline Sweet potato feathery mottle virus & SPFMV & Potyviridae (Potyvirus) & Aphid (non-persistent) \\
Sweet potato virus G & SPVG & Potyviridae (Potyvirus) & Aphid (non-persistent) \\
Sweet potato latent virus & SPLV & Potyviridae (Potyvirus) & Aphid (non-persistent) \\
Sweet potato leaf curl virus ${ }^{a}$ & SPLCV & Geminiviridae (Begomovirus) & Whitefly (persistent) \\
Sweet potato mild speckling virus & SPMSV & Potyviridae (Potyvirus) & Aphid (non-persistent) \\
Sweet potato mild mottle virus & SPMMV & Potyviridae (Ipovirus) & Whitefly (persistent) \\
Sweet potato chlorotic stunt virus & SPCSV & Closteroviridae (Crinivirus) & Whitefly(non-persistent) \\
Sweet potato collusive virus & SPCV & Caulimoviridae(Cavemovirus) & $*$ \\
Sweet potato virus 2 & SPV2 & Potyviridae (Potyvirus) & Aphid (non-persistent) \\
Sweet potato virus C & SPVC & Potyviridae (Potyvirus) & Aphid (non-persistent) \\
Sweet potato symptomless virus 1 & SPSMV-1 & Geminiviridae (Mastrevirus) & $*$ \\
Sweet potato chlorotic fleck virus & SPCFV & Betaflexiviridae (Carlavirus) & $*$ \\
Sweet potato vein clearing virus & SPVCV & Caulimoviridae (Solendovirus) & $*$ \\
Sweet potato pakakuy virus & SPPV & Caulimoviridae (Badnavirus) & $*$ \\
Sweet potato C6 virus & SPC6V & Betaflexiviridae (Carlavirus) & $*$ \\
Sweet potato leaf speckling virus & SPLSV & Luteoviridae (Polerovirus) & $*$ \\
Cucumber mosaic virus & CMV & Bromoviridae (Cucumovirus) & Aphid (non-persistent) \\
\hline
\end{tabular}

${ }^{a}$ Sweet potato leaf curl virus has been classified into seven species: Sweet potato leaf curl virus (SPLCV), Ipomoea yellow vein virus (IYVV), Sweet potato leaf curl Georgia virus (SPLCGoV), Sweet potato leaf curl China virus (SPLCV-CN), Sweet potato leaf curl Lanzarote virus (SPLCLaV), Sweet potato leaf curl Canary virus (SPLCCaV), and Sweet potato leaf curl Spain virus (SPLCESV) by ICTV. *Not reported.

et al., 2006). Our previous nationwide survey revealed that, in 2003 , about $73 \%$ of samples were infected with at least one of these four viruses (Kwak et al., 2006). SPFMV and SPVG were especially prevalent (40\% and 16\%, respectively), and coinfection with SPFMV and SPVG was detected in $11 \%$ of diseased sweet potatoes. Although SPCSV was reported by Yun et al. (2002), it has not subsequently been detected in Korea.

In the present study, we established detection methods for 17 major sweet potato viruses using reverse transcription-polymerase chain reaction (RT-PCR), and investigated the current incidence of viral disease in Korean sweet potatoes by analyzing 154 samples of various cultivars showing virus-like symptoms collected from 40 fields in 10 regions. Finally, we developed multiplex RT-PCR methods for simple and simultaneous detection of the eight sweet potato viruses known to occur in Korea.

\section{Materials and Methods}

Survey and sample collection. In 2012, we carried out a survey of sweet potato viruses in 40 seedling-cultured fields of sweet potatoes in 10 regions of 5 different Korean provinces (Fig. 1). We collected samples of 154 sweet potato leaves (including petiole and stem) showing virus-like symptoms. The collected samples were treated with insec- ticides to remove potential insect vectors and maintained in pots in a greenhouse at $20-25^{\circ} \mathrm{C}$ (Table 2). All samples were inspected for disease symptoms for at least 30 days and analyzed for virus infection by RT-PCR.

Total nucleic acids extraction and virus detection by RT-PCR. We extracted total nucleic acids from the infected leaf, petiole and stem samples using the Viral gene$\operatorname{spin}^{\mathrm{TM}}$ viral DNA/RNA extraction kit (iNtRON, Korea), according to the manufacturer's instructions. Typical RTPCR assays were carried out using the primers shown in Table 3 in a two-step procedure using AMV reverse transcriptase (Promega, USA) for RT and Go-taq polymerase (Promega, USA) for PCR, as described by Kwak et al. (2013). Multiplex RT-PCR assays were performed using two-step RT-PCR or one-step RT-PCR. In the case of twostep RT-PCR, RT reactions were carried out at $42^{\circ} \mathrm{C}$ for $30 \mathrm{~min}$ in a final $5 \mu \mathrm{l}$ reaction obtained by combining 0.5 $\mu \mathrm{l}$ total RNA (approx. $0.5 \mu \mathrm{g}$ ), $0.5 \mu \mathrm{l}$ of a mixture of equal amounts of $32 \mu \mathrm{M}$ reverse primers for four viruses, $1 \mu \mathrm{l} 5 \times$ RT buffer, $0.5 \mu \mathrm{l} 2.5 \mu \mathrm{M}$ dNTP, $0.1 \mu \mathrm{l} \mathrm{BSA} \mathrm{(10} \mathrm{mg/ml),} 8$ U RNase inhibitor, $0.5 \mathrm{U}$ AMV reverse transcriptase (Promega, USA), and sufficient $\mathrm{dH}_{2} \mathrm{O}$ to bring the total to $5 \mu \mathrm{l}$. RT reactions were terminated by heating at $95^{\circ} \mathrm{C}$ for $5 \mathrm{~min}$. When RT was completed, we added $20 \mu$ of a solution comprising $0.5 \mu \mathrm{l}$ of a mixture of equal amounts of $32 \mu \mathrm{M}$ 


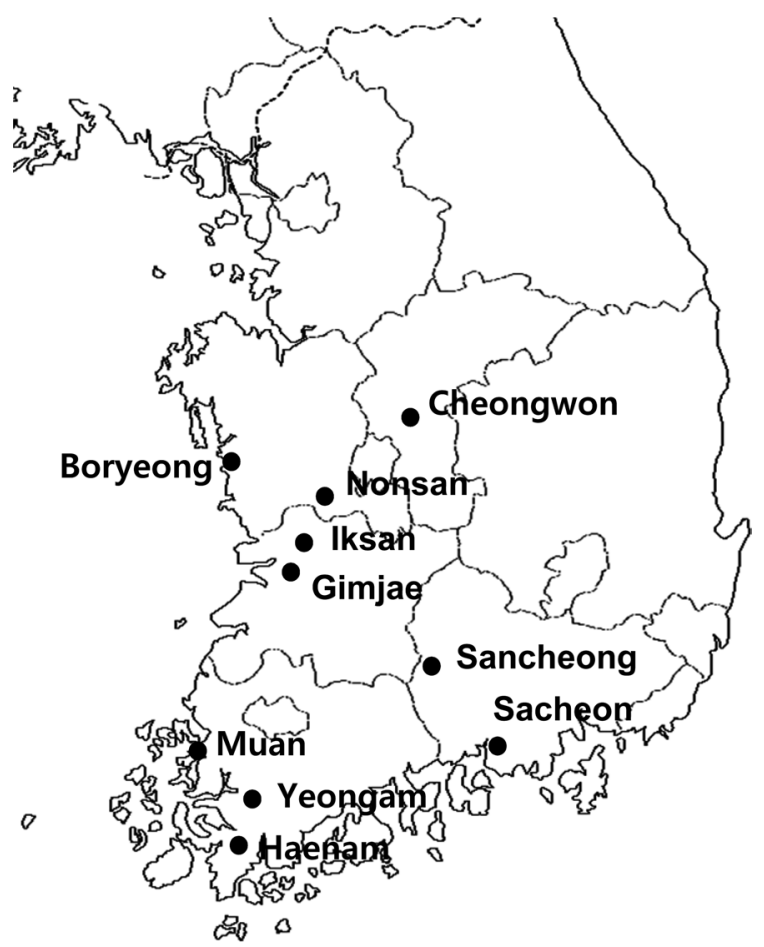

Fig. 1. Geographic location of the sweet potato fields surveyed in 2012. A total of 154 sweet potato specimens were collected from 40 cultivated fields in 10 regions of 5 Korean provinces, as indicated.

forward primers for four viruses, $5 \mu \mathrm{l} 5 \times \mathrm{PCR}$ buffer, 2.5 $\mu \mathrm{L} 25 \mathrm{mM} \mathrm{MgCl} 2,0.4 \mu \mathrm{lBSA}(10 \mathrm{mg} / \mathrm{ml}), 1 \mathrm{U}$ Go-Taq DNA polymerase (Promega, USA), and $\mathrm{dH}_{2} \mathrm{O}$ to the tube containing RT products. PCR was performed in a thermal cycler (Bio-Rad, USA) with the following conditions: predenaturing step at $94^{\circ} \mathrm{C}$ for $5 \mathrm{~min} ; 35$ cycles of a denaturing step at $94^{\circ} \mathrm{C}$ for $30 \mathrm{~s}$; an annealing step at $55^{\circ} \mathrm{C}$ for $30 \mathrm{~s}$; an extension step at $72^{\circ} \mathrm{C}$ for $60 \mathrm{~s}$; and a final extension at $72^{\circ} \mathrm{C}$ for $10 \mathrm{~min}$. One-step RT-PCR was performed in a 20 $\mu l$ reaction containing total RNA (approx. $0.5 \mu \mathrm{g}$ ), a mixture of equal amounts of $32 \mu \mathrm{M}$ forward and reverse primers for four viruses, and RT-PCR master mix (GenetBio, Korea) under the following conditions: $30 \mathrm{~min}$ at $50^{\circ} \mathrm{C} ; 10$ min at $94^{\circ} \mathrm{C}$; and 35 cycles consisting of $20 \mathrm{~s}$ at $94^{\circ} \mathrm{C}, 30$ $\mathrm{s}$ at $55^{\circ} \mathrm{C}, 60 \mathrm{~s}$ at $72^{\circ} \mathrm{C}$, and $5 \mathrm{~min}$ at $72^{\circ} \mathrm{C}$. PCR products were analyzed by electrophoresis on a $1.5 \%$ agarose gel at $100 \mathrm{~V}$ for $90 \mathrm{~min}$, stained with ethidium bromide, and DNA bands were visualized using a UV transilluminator.

Primer design. Specific primers for the detection of sweet potato viruses were designed based on the reported nucleotide sequences of various sweet potato virus isolates retrieved from the GenBank of the National Center for Biotechnology Information (Table 3). In particular, the primers
Table 2. Legend of sweet potato specimens analyzed in this study

\begin{tabular}{llcc}
\hline Province & Regions $^{\mathrm{a}}$ & \multicolumn{2}{c}{$\begin{array}{c}\text { No. of fields No. of samples } \\
\text { investigated }\end{array}$} \\
\hline \multirow{3}{*}{ collected }
\end{tabular}

${ }^{a}$ Regions and fields selected for sample collection were within major Korean sweet potato production areas in 2012.

${ }^{b}$ Samples of sweet potato leaves (including petiole and stem) showing virus-like symptoms were collected.

for multiplex RT-PCR were designed to have similar melting temperatures and selected so as not to produce nonspecific bands. Two sets of the multiplex detection primers and the expected sizes of the amplicons are listed in Table 3.

\section{Results}

Incidence of viral disease in Korean sweet potatoes in 2012. To investigate the current incidence of viral disease in Korean sweet potatoes, we collected 154 samples from various seedling-cultured sweet potato cultivars in 10 regions of 5 Korean provinces in 2012. We observed various representative symptoms on the infected sweet potato samples, including vein clearing, vein banding, chlorotic local lesions, purpling, malformation, and leaf curling (Fig. 2). We analyzed samples by RT-PCR using specific primers designed to detect 17 major viruses infecting sweet potato (Table 3). In case of SPLCV, universal primers were used to detect seven SPLCV species (Table 1). Among the 17 viruses tested, we detected 8, including 4 viruses not previously detected in Korea (Sweet potato virus C [SPVC], Sweet potato virus 2 [SPV2], Sweet potato chlorotic fleck virus [SPCFV], and Sweet potato symptomless virus 1 [SPSMV-1]; Table 4). SPFMV and SPVC were detected most often, in about $87 \%$ and $85 \%$ of samples, respectively, including in mixed infections with other viruses (Table 4). Furthermore, SPSMV-1, SPVG, SPLCV, SPV2, SPCFV, and SPLV were detected in $67 \%, 58 \%, 47 \%, 41 \%$, 
Table 3. Primers used in multiplex and single RT-PCR assays for the detection of major sweet potato-infecting viruses

\begin{tabular}{|c|c|c|c|c|}
\hline Virus & Primer $^{a}$ & Sequence $\left(5^{\prime} \rightarrow 3^{\prime}\right)$ & Loci & Size (nt) \\
\hline \multicolumn{5}{|c|}{ Multiplex RT-PCR primer set 1} \\
\hline \multirow{2}{*}{ SPLCV } & SPLC-u1 & TCTGCCGTCGATCTGGAACTC & $2315-2335$ & \multirow{2}{*}{507} \\
\hline & SPLC-d1 & GTGCCCGCCTTTGGTGGAC & $2821-2803$ & \\
\hline \multirow{2}{*}{ SPFMV } & SPFMV 1-F & TACACACTGCTAAAACTAGG & $9073-9092$ & \multirow{2}{*}{356} \\
\hline & SPFMV 1-R & AGTTCATCATAACCCCATGA & $9428-9409$ & \\
\hline \multirow{2}{*}{ SPVG } & SPG 3-F & CAATGCCAAATGGAAGAATAG & $9945-9965$ & \multirow{2}{*}{286} \\
\hline & SPG 3-R & GCATGATCCAATAGAGGTTTTA & $10230-10209$ & \\
\hline \multirow[b]{2}{*}{ SPLV } & SPLV 1-F & GGAGTCAGTTCAATCAATGGTA & $9340-9361$ & \multirow[b]{2}{*}{184} \\
\hline & SPLV 1-R & AGTGGCTTTATTGGGTATGAT’ & $9523-9503$ & \\
\hline \multicolumn{5}{|c|}{ Multiplex RT-PCR primer set 2} \\
\hline \multirow{2}{*}{ SPCFV } & SPCFV $2 \mathrm{~F}$ & AGCTGCTCAAACAAGCAAGAGG & $8526-8547$ & \multirow{2}{*}{579} \\
\hline & SPCFV 2R & GCTCAAAAGTACTTTAAAACATGC & $9104-9081$ & \\
\hline \multirow{2}{*}{ SPVC } & SPVC-F & ATTCTTGAATGGGATAGATCACATG & $9353-9377$ & \multirow{2}{*}{447} \\
\hline & SPVC-R & AGCTTCACGAAGCGCAGC & 9799-9782 & \\
\hline \multirow{2}{*}{ SPV2 } & SPV2-F1 & ATGTGTTGAACCATCAGCTGAA & $9414-9435$ & \multirow{2}{*}{369} \\
\hline & SPV2-R1 & GTAACTTGCCTTGGGCTACG & $9782-9763$ & \\
\hline \multirow{2}{*}{ SPSMV-1 } & SPSMV-1 F1 & ACCGTGTATTTGATGACGATGTAC & $352-375$ & \multirow[b]{2}{*}{230} \\
\hline & SPSMV-1 R & GGGAAGTTCTGGTAGAACGTATC & $581-559$ & \\
\hline \multicolumn{5}{|c|}{$\underline{\text { Single RT-PCR primers }}^{\mathrm{b}}$} \\
\hline \multirow{2}{*}{ SPMMV } & SPMMV 3-F & CCGCGCCAACAA AGGAACTA & $9842-9861$ & \multirow{2}{*}{298} \\
\hline & SPMMV 3-R & TTGATGGGGTAATAAAGCACT & $10140-10120$ & \\
\hline \multirow{2}{*}{ SPCSV } & SPCSV-uni-f1 & GGGAAGAMGAGAYATGGAGTTAA & $4484-4506$ & \multirow{2}{*}{583} \\
\hline & SPCSV-uni-r1 & CCTTGTTACAAAGAGCGTTCCT & $5066-5045$ & \\
\hline \multirow{2}{*}{ SPMSV } & SPMSV 1-F & GCCAAAACCAACAAGCATCA & $105-124$ & \multirow{2}{*}{275} \\
\hline & SPMSV 1-R & ATTCGCATTTCCTCATCATCT & $380-360$ & \\
\hline \multirow{2}{*}{ SPCV } & SPCV F & AGGAAATCCCAGTATTATTCAAC & $4267-4289$ & \multirow{2}{*}{922} \\
\hline & SPCV R & ATTTCTAATTTGGTTTACTAATCC & $5188-5165$ & \\
\hline \multirow{2}{*}{ SPVCV } & SPVCV-F & ATCCATTGCCAAATAAGATATTAAGA & $5844-5870$ & 308 \\
\hline & SPVCV-R & CTTCTTAAGCAATGTTTCATGCTC & $6151-6128$ & 500 \\
\hline SPPY & SPPV-F & ATGAGGAGAA(C)CAGGGGCC & $1486-1503$ & 722 \\
\hline & SPPV-R & CCAACG(A)TTTGGAGTGTTGGAT & $2207-2187$ & \\
\hline SPC6V & SPC6V-F1 & AAAAGCTTGTTGGCAATTTGTG & $6804-6825$ & 590 \\
\hline 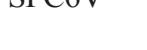 & SPC6V-R1 & TTGGCATTTCGATTGTCCC & $7393-7376$ & 格 \\
\hline SPI SV & SPLSV-F & ATGAGTACGGTCGTGGTTAGAAAC & $1-24$ & 612 \\
\hline S LS & SPLSV-R & CTACCTATTTGGGTTCTGGAAGG & $612-590$ & 012 \\
\hline CMV & CMV-DP u & CGTCGTGGTTCCCGCTCCG & $1309-1327$ & 474 \\
\hline CIVI & CMV-DP d2 & AGCGCGCATCGCCGAAAGAT & $1782-1763$ & $4 / 4$ \\
\hline
\end{tabular}

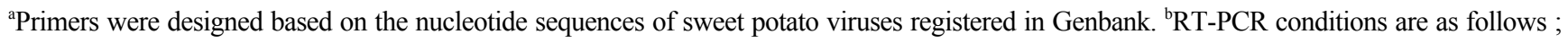
$30 \mathrm{~min}$ at $42^{\circ} \mathrm{C}, 5 \mathrm{~min}$ at $94^{\circ} \mathrm{C}$, and 35 cycles consisting of $20 \mathrm{~s}$ at $94^{\circ} \mathrm{C}, 30 \mathrm{~s}$ at $55^{\circ} \mathrm{C}, 60 \mathrm{~s}$ at $72^{\circ} \mathrm{C}$, and 5 min at $72^{\circ} \mathrm{C}$.

$31 \%$, and $20 \%$ of the collected samples, respectively (Table 4). While SPFMV, SPVC, SPVG, SPV2, and SPLCV were detected in all surveyed areas, SPLV and SPSMV-1 were not detected in Boryeong and Sancheong, respectively, and SPCFV was not detected in Nonsan or Boryeong (Table 4). All samples but one were infected with at least one of the eight viruses (Table 5). Only 3.9\% of the samples were singly infected with one of the eight viruses, while $95.5 \%$ of the samples were found in mixed infections (Table 5). The total rates of double, triple, quadruple, quintuple, sextuple, septuple, and octuple infections were $8.4 \%, 12.3 \%$, $20.8 \%, 32.5 \%, 19.5 \%, 1.3 \%$, and $0.6 \%$, respectively. The most prevalent infection type was quintuple infection with SPFMV, SPVC, and other viruses (Table 5). 


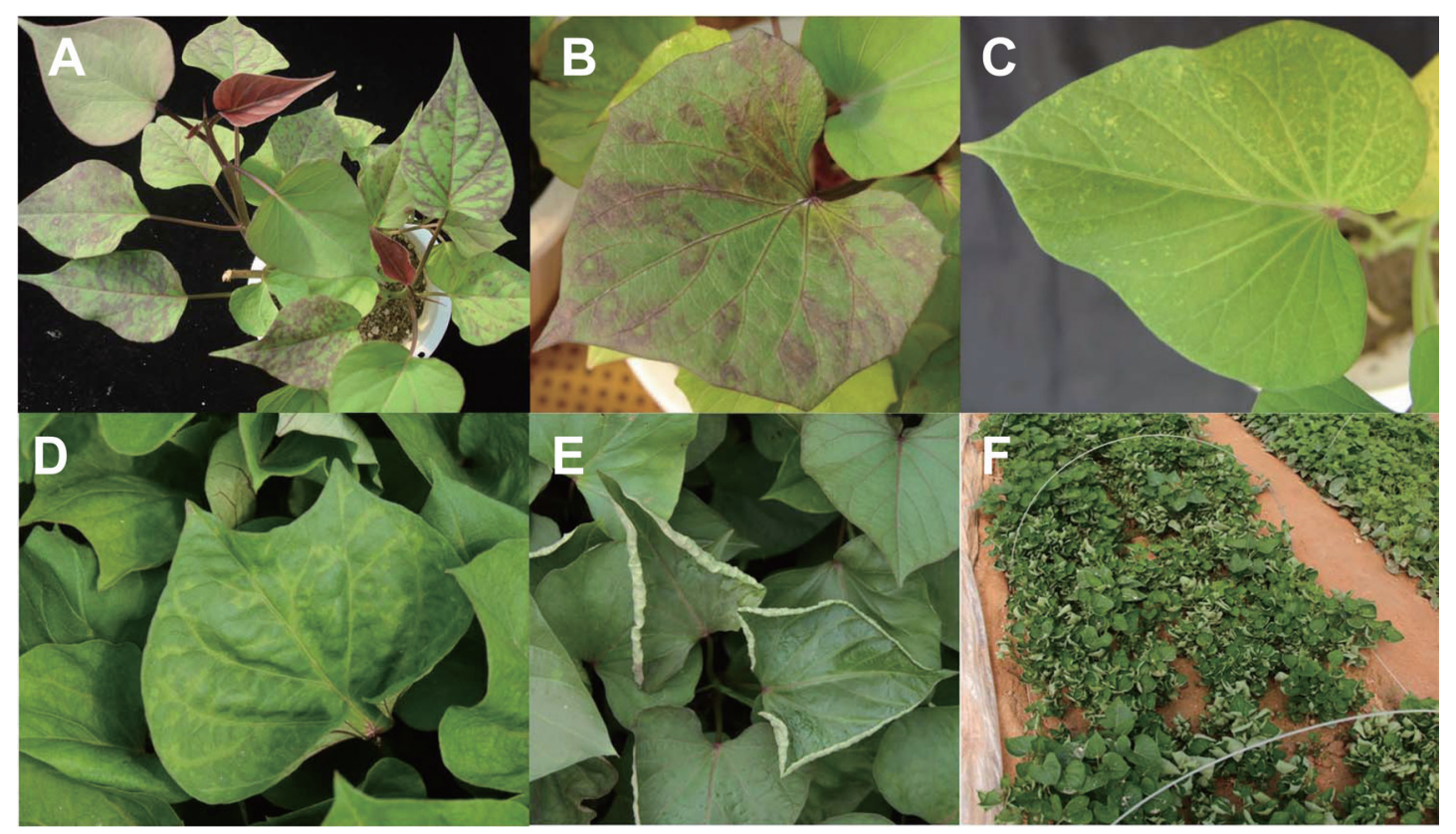

Fig. 2. Representative virus symptoms observed in sweet potato: (A) vein banding and purpling; (B) chlorotic local lesions and purpling; (C) vein clearing and mottle; (D) vein clearing and leaf malformation; (E) leaf curling; (F) leaf curling in a cultivated field.

Table 4. Incidence of sweet potato viruses in samples of seedling-cultured sweet potatoes collected in 2012

\begin{tabular}{|c|c|c|c|c|c|c|c|c|c|c|}
\hline \multirow{2}{*}{\multicolumn{2}{|c|}{ Province/Region }} & \multirow{2}{*}{$\begin{array}{c}\text { No. of } \\
\text { samples }\end{array}$} & \multicolumn{8}{|c|}{ No. of virus detections by RT-PCR ${ }^{\mathrm{a}}$} \\
\hline & & & SPFMV & SPVC & SPVG & SPV2 & SPLV & SPCFV & SPLCV & SPSMV-1 \\
\hline \multirow{3}{*}{ Jeollanam-do } & Haenam & 40 & 40 & 40 & 17 & 17 & 8 & 17 & 20 & 29 \\
\hline & Yeongam & 10 & 10 & 10 & 7 & 8 & 2 & 1 & 3 & 10 \\
\hline & Muan & 37 & 25 & 27 & 13 & 3 & 2 & 12 & 22 & 34 \\
\hline \multirow{2}{*}{ Jeollabuk-do } & Iksan & 16 & 13 & 7 & 10 & 7 & 1 & 1 & 6 & 6 \\
\hline & Gimje & 14 & 10 & 11 & 8 & 4 & 6 & 3 & 7 & 11 \\
\hline \multirow{2}{*}{ Gyeongsangnam-do } & Sancheong & 13 & 13 & 13 & 12 & 8 & 6 & 9 & 4 & 0 \\
\hline & Sacheon & 4 & 4 & 4 & 4 & 2 & 3 & 2 & 2 & 1 \\
\hline Chungcheongbuk-do & Cheongwon & 7 & 7 & 6 & 6 & 4 & 1 & 2 & 5 & 5 \\
\hline \multirow{2}{*}{ Chungcheongnam-do } & Nonsan & 3 & 3 & 3 & 3 & 2 & 1 & 0 & 1 & 2 \\
\hline & Boryeong & 10 & 9 & 10 & 9 & 8 & 0 & 0 & 3 & 5 \\
\hline Total & 10 & 154 & 134 & 131 & 89 & 63 & 30 & 47 & 73 & 103 \\
\hline Ratio (\%) & & & 87 & 85 & 58 & 41 & 20 & 31 & 47 & 67 \\
\hline
\end{tabular}

ancluding single and mixed infections.

Development of multiplex RT-PCR assays for simultaneous detection of sweet potato viruses. For simultaneous detection of sweet potato-infecting viruses occurring in Korea, we developed two multiplex RT-PCR assays for the eight major viruses including SPLCV, SPFMV, SPVG, and SPLV in one set, and SPCFV, SPVC, SPV2, and SPSMV-1 in another (Table 3). The primer sets of the assays were designed to generate different sizes of amplicons for the target viruses (Table 3). Each primer pair was highly specific and did not cross-amplify to other viral or sweet potato nucleic acids (Figs. 3 and 4, lanes 1-4). The specificity of each primer pair was confirmed by sequencing the RT-PCR products. Simultaneous detection of all possible combinations among SPLCV, SPFMV, SPVG, and SPLV was performed by multiplex RT-PCR using the singly or mixed-infection field samples (Fig. 3). Likewise, we also performed simultaneous detection of all possible combinations among SPCFV, SPVC, SPV2, and 
Table 5. Mixed infection types of eight sweet potato viruses

\begin{tabular}{|c|c|c|c|c|c|c|c|c|c|c|}
\hline \multirow{2}{*}{$\begin{array}{l}\text { Mixed infection } \\
\text { type }\end{array}$} & \multicolumn{10}{|c|}{ Detected viruses } \\
\hline & SPFMV & SPVC & SPVG & SPV2 & SPLV & SPCFV & SPLCV & SPSMV-1 & Subtotal & Total $(\%)$ \\
\hline Octuple & + & + & + & + & + & + & + & + & 1 & $1(0.6)$ \\
\hline \multirow{2}{*}{ Septuple } & + & + & + & + & + & + & + & - & 1 & \multirow{2}{*}{$2(1.3)$} \\
\hline & + & + & + & - & + & + & + & + & 1 & \\
\hline \multirow{10}{*}{ Sextuple } & + & + & + & + & + & + & - & - & 4 & \multirow{10}{*}{$30(19.5)$} \\
\hline & + & + & + & + & + & - & + & - & 6 & \\
\hline & + & + & + & + & + & - & - & + & 3 & \\
\hline & + & + & + & + & - & + & + & - & 1 & \\
\hline & + & + & + & + & - & - & + & + & 6 & \\
\hline & + & + & + & - & + & + & + & - & 2 & \\
\hline & + & + & + & - & + & - & + & + & 3 & \\
\hline & + & + & + & - & - & + & + & + & 1 & \\
\hline & + & + & - & + & - & + & + & + & 2 & \\
\hline & + & + & - & - & + & + & + & + & 2 & \\
\hline \multirow{9}{*}{ Quintuple } & + & + & + & + & + & - & + & - & 4 & \multirow{9}{*}{$50(32.5)$} \\
\hline & + & + & + & + & - & + & - & - & 3 & \\
\hline & + & + & + & + & - & - & + & - & 6 & \\
\hline & + & + & + & + & - & - & - & + & 12 & \\
\hline & + & + & + & - & + & + & - & - & 1 & \\
\hline & + & + & + & - & - & + & + & - & 1 & \\
\hline & + & + & + & - & - & - & + & + & 8 & \\
\hline & + & + & - & + & - & + & - & + & 2 & \\
\hline & + & + & - & - & - & + & + & + & 13 & \\
\hline \multirow{12}{*}{ Quadruple } & + & + & + & + & - & - & & - & 6 & \multirow{12}{*}{$32(20.8)$} \\
\hline & + & + & + & - & - & + & - & - & 1 & \\
\hline & + & + & + & - & - & - & + & - & 2 & \\
\hline & + & + & + & - & - & - & - & + & 7 & \\
\hline & + & + & - & + & - & - & + & - & 1 & \\
\hline & + & + & - & + & - & - & - & + & 2 & \\
\hline & + & + & - & - & - & + & - & + & 7 & \\
\hline & + & + & - & - & - & - & + & + & 2 & \\
\hline & + & - & + & + & - & - & - & + & 1 & \\
\hline & + & - & + & - & + & + & - & - & 1 & \\
\hline & + & - & + & - & + & - & + & - & 1 & \\
\hline & - & + & - & - & - & + & + & + & 1 & \\
\hline \multirow{8}{*}{ Triple } & + & + & + & - & - & - & - & - & 2 & \multirow{8}{*}{$19(12.3)$} \\
\hline & + & + & - & + & - & - & - & - & 2 & \\
\hline & + & + & - & - & - & - & + & - & 1 & \\
\hline & + & + & - & - & - & - & - & + & 7 & \\
\hline & + & - & - & - & - & - & + & + & 1 & \\
\hline & - & + & - & - & - & - & + & + & 4 & \\
\hline & - & + & + & - & - & - & - & + & 1 & \\
\hline & - & - & - & - & - & + & + & + & 1 & \\
\hline \multirow{7}{*}{ Double } & + & - & + & - & - & - & - & - & 1 & \multirow{7}{*}{$13(8.4)$} \\
\hline & + & - & - & - & - & - & + & - & 1 & \\
\hline & + & - & - & - & - & - & - & + & 4 & \\
\hline & - & + & - & - & - & - & - & + & 2 & \\
\hline & - & - & + & - & - & - & - & + & 2 & \\
\hline & - & - & - & - & - & + & - & + & 1 & \\
\hline & - & - & - & - & - & - & + & + & 2 & \\
\hline \multirow{3}{*}{ Single } & + & - & - & - & - & - & - & - & 1 & \multirow{3}{*}{$6(3.9)$} \\
\hline & - & - & - & - & - & - & + & - & 1 & \\
\hline & - & - & - & - & - & - & - & + & 4 & \\
\hline No detection & - & - & - & - & - & - & - & - & 1 & $1(0.6)$ \\
\hline Total & & & & & & & & & & \\
\hline
\end{tabular}




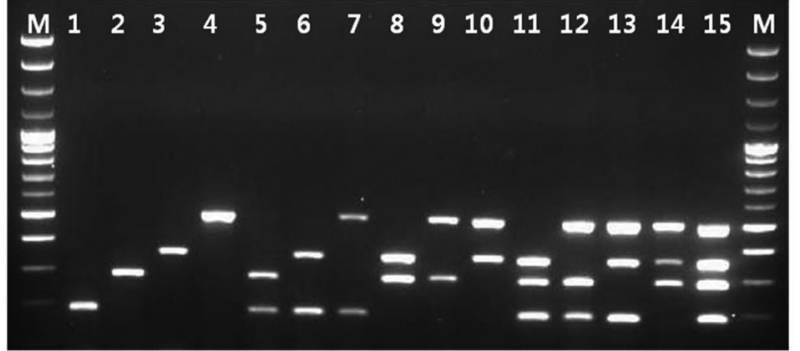

Fig. 3. Simultaneous detection of all possible combinations among SPLCV, SPFMV, SPVG, and SPLV by multiplex RTPCR. Lane M: 100 bp ladder; Lane 1: SPLV; Lane 2: SPVG; Lane 3: SPFMV; Lane 4: SPLCV; Lane 5: SPLV and SPVG; Lane 6: SPLV and SPFMV; Lane 7: SPLV and SPLCV; Lane 8: SPVG and SPFMV; Lane 9: SPVG and SPLCV; Lane 10: SPFMV and SPLCV; Lane 11: SPLV, SPVG, and SPFMV; Lane 12: SPLV, SPVG, and SPLCV; Lane 13: SPLV, SPFMV, and SPLCV; Lane 14: SPVG, SPFMV, and SPLCV; Lane 15: SPLV, SPVG, SPFMV, and SPLCV.

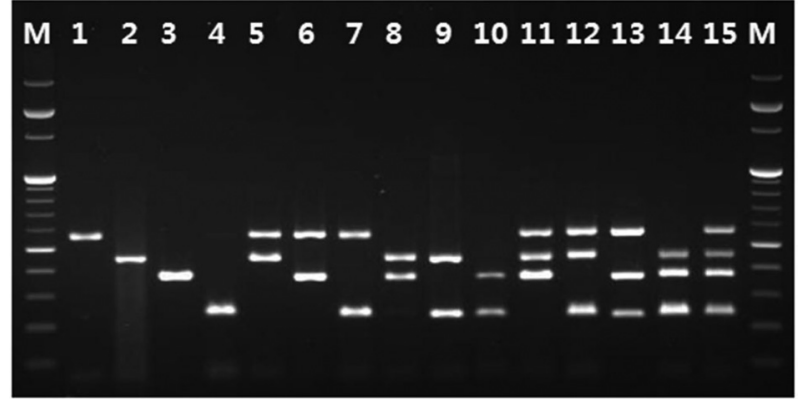

Fig. 4. Simultaneous detection of all possible combinations among SPCFV, SPVC, SPV2, and SPSMV-1 by multiplex RTPCR. Lane M: 100 bp ladder; Lane 1: SPCFV; Lane 2: SPVC; Lane 3: SPV2; Lane 4: SPSMV-1; Lane 5: SPCFV and SPVC; Lane 6: SPCFV and SPV2; Lane 7: SPCFV and SPSMV-1; Lane 8: SPVC and SPV2; Lane 9: SPVC and SPSMV-1; Lane 10: SPV2 and SPSMV-1; Lane 11: SPCFV, SPVC, and SPV2; Lane 12: SPCFV, SPVC, and SPSMV-1; Lane 13: SPCFV, SPV2, and SPSMV-1; Lane 14: SPVC, SPV2, and SPSMV-1; Lane 15: SPCFV, SPVC, SPV2, and SPSMV-1.

SPSMV-1 by multiplex RT-PCR (Fig. 4). Various field samples of virus-infected sweet potatoes were subjected to the multiplex RT-PCR assays developed in this study, resulting in reliable and sensitive detection and identification of major sweet potato viruses (data not shown).

\section{Discussion}

In Korea, SPFMV, SPLV, SPVG, and SPLCV have previously been reported to infect sweet potato (Kwak et al., 2006). In this study, a nationwide survey was performed to investigate the current incidence of viral diseases in Korean sweet potatoes. To this end, we analyzed 154 samples of sweet potatoes showing virus-like symptoms by single or multiplex RT-PCR assays to detect 17 major viruses. Our survey revealed that eight viruses (including four that were previously undocumented: SPVC, SPV2, SPSMV-1, and SPCFV) infect sweet potatoes in Korea. However, other nine viruses (SPCSV, SPMSV, SPMMV, SPCV, SPVCV, SPPV, SPC6V, SPLSV, and CMV) were not detected in our survey. Although the primers used in this study were designed based on the highly conserved regions of each target virus, we could not excluded the possibility that the primers failed to amplify the targets efficiently because positive controls for RT-PCR detection of these viruses were not available in this study. Therefore, we note that our survey results did not conclude that the examined samples were not infected with the undetected viruses.

Six viruses (SPFMV, SPVC, SPVG, SPV2, SPLV, and SPMSV) are members of the genus Potyvirus, in the family Potyviridae (Adams et al., 2011; Clark et al., 2012). Among these potyviruses, five viruses but SPMSV had a high incidence $(96 \%, 148 / 154$ samples collected) in Korea, and SPFMV was especially prevalent. SPFMV has been divided into four representative strains: Russet Crack (RC), Ordinary (O), East Africa (EA), and Common (C) (Abad et al., 1992; Kreuze et al., 2000; Kwak et al., 2007). However, because SPFMV strain C has a relatively low homology with the other SPFMV strains, it was reclassified as a new species, SPVC, by ICTV in 2010. A previous study showed that Korean SPFMV isolates are similar to the RC and O strains, but did not detect any EA-like isolates (Kwak et al., 2007). The EA strain has been detected exclusively in East Africa as a distinct group (Kreuze et al., 2000; Mukasa et al., 2003). However, it was also found in Peru (Untiveros et al., 2008), Vietnam (Ha et al., 2008), Easter Island (Rännäli et al., 2009) and recently in China (Qin et al., 2013). The other potyviruses infecting sweet potato (SPVG, SPLV, and SPV2) have been poorly studied; however, their complete genome sequences were recently reported and compared to SPFMV (Li et al., 2012a; Rodriguez Pardina et al., 2012; Wang et al., 2013). Similar to SPFMV, SPLV was reported to cause synergistic disease when coinfected with SPCSV (Untiveros et al., 2007). SPV2 was first isolated from Taiwan and Nigeria (Rossel et al., 1988) and has distinct biological, serological, and genetic characteristics from SPFMV (Ateka et al., 2007; Li et al., 2012).

Begomoviruses infecting sweet potato are widely distributed worldwide. Twelve sweet potato viruses belonging to the genus Begomovirus in the family Geminiviridae have been reported (Clark et al., 2012), of which seven have 
been accepted as virus species by the ICTV (Table 1). Incidence of SPLCV in Korea increased markedly from 5\% in 2003 to $47 \%$ in 2012 (Kwak et al., 2006). This study provides the first record of SPSMV-1 (of the genus Mastrevirus in the family Geminiviridae) in Korea; we detected it frequently ( $\sim 67 \%$ ) in most areas, with the exception of Sancheong, in Gyeongsangnam-do. Several SPSMV-1 isolates have been identified from Peru, Tanzania, and China, showing 100\% homology in the CP-MP region (Clark et al., 2012; Kreuze et al., 2009). SPCFV (a member of the genus Carlavirus in the family Betaflexiviridae) was first detected in sweet potato showing fine chlorotic spots in Peru. It has since been detected in several countries of South America, Asia, and South Africa and the complete genome sequence of an isolate from Uganda has been characterized (Aritua et al., 2007). Untiveros et al. showed that SPCFV could cause a synergistic disease when sweet potatoes were coinfected with SPCSV. The present study provides the first report of SPCFV in Korea, and we found that it occurred in $\sim 31 \%$ of samples collected in most areas except Chungcheongnam-do (Table 4).

Most of the samples were in mixed infections with at least two of the eight viruses (Table 5). The single and mixed infection rates were $3.9 \%$ and $95.5 \%$, respectively. The most prevalent infection type (32.5\%) was quintuple infection with SPFMV, SPVC, and other viruses. We did not detect single infection of SPVC, SPVG, SPV2, SPLV, or SPCFV (Table 5).

In comparison, among 179 sweet potato samples surveyed in 2003, 73\% were infected with SPFMV, SPGV, SPLV, and SPLCV, whereas $27 \%$ remained unidentified despite showing virus-like symptoms. However, of the samples collected in 2012, all but one was infected with one or several of the eight aforementioned viruses. In particular, we confirmed that six out of seven samples, which were thought to be virus-free, were actually infected with new viruses (data not shown). Although we detected some differences in virus type and in the degree of multiple infection among sample locations, overall infection rates were consistently high. Consequently, it is essential to test for at least these eight viruses in order to produce virus-free sweet potato seedlings in Korea.

Recently, viral diseases have caused severe damage to sweet potato crops. Thus, detection and identification of viral pathogens is vital for producing virus-free sweet potato seedlings and preventing the spread of viruses. Besides, because most of sweet potatoes were infected with a different combination of viruses, multiplex RT-PCR methods for simultaneous detection of several viruses in one reaction have been developed (Li et al., 2012b; Opiyo et al., 2010;
Rukarwa et al., 2010). For rapid, simple, and simultaneous detection of sweet potato-infecting viruses in Korea, we developed two multiplex RT-PCR assays for eight major viruses, including SPLCV, SPFMV, SPVG, and SPLV in one set, and SPCFV, SPVC, SPV2, and SPSMV-1 in another set. We performed these multiplex RT-PCR methods via two-step or one-step reactions and applied them to a variety of sweet potato samples. In case of primer set 1 designed for detecting SPLCV, SPFMV, SPVG and SPLV, two-step multiplex RT-PCR performed well but unfortunately one-step multiplex RT-PCR did not work. Also, in case of primer set 2 designed for detecting SPCFV, SPVC, SPV2 and SPSMV-1, both one-step and two-step multiplex RT-PCRs were successfully. To evaluate the specificity of the assays, we confirmed the amplified products by sequencing. The multiplex RT-PCR assays developed in this study will provide a rapid, convenient, and cost-efficient method for the detection of multiple viruses in sweet potato.

\section{Acknowledgments}

This work was supported by a grant from the Agenda Program (PJ006519) of the Rural Development Administration, the Korea Institute of Planning and Evaluation for Technology in Food, Agriculture, Forestry, and Fisheries (iPET: No. 110034-05-3-HD110), and the Ministry of Food, Agriculture, Forestry, and Fisheries, Republic of Korea.

\section{References}

Abad, J. A., Conkling, M. A. and Moyer, J. W. 1992. Comparison of the capsid protein cistron from serologically distinct strains of Sweet potato feathery mottle virus (SPFMV). Arch. Virol. 126:147-157.

Adams, M. J., Zerbini, F. M., French, R., Rabenstein, F., Stenger, D. C., Valkonen, J. P. T. in Virus Taxonomy, ed. by King, A. M. Q., Lefkowitz, E. Adams, M. J. and Carstens, E. B. 2011. 9th Report of the International Committee for Taxonomy of Viruses. Elsevier Academic Press, San Diego. pp 1069-1089.

Aritua, V., Barg, E., Gibson, R. W., Adipala, E. and Vetten, H. J. 2007. Sequence analysis of the entire RNA genome of Sweet potato chlorotic fleck virus reveals that it belongs to a distinct carlavirus species. Arch. Virol. 152:813-818.

Ateka, E. M., Barg, E., Njeru, R. W., Thompson, G. and Vetten, H. J. 2007. Biological and molecular variability among geographically diverse isolate of Sweet potato virus 2. Arch. Virol. 152:479-488.

Brunt, A. A., Crabtree, K., Dallwitz, M. J., Gibbs, A. J. and Watson, L. 1996. Viruses of Plants. Descriptions and Lists from the VIDE Database. CAB International, Wallingford, UK.

Clark, C. A., Davis, J. A., Abad, J. A., Cuellar, W. J., Fuentes, S., 
Kreuze, J. F., Gibson, R. W., Mukasa, S. B., Tugume, A. K., Tairo, F. and Valkonen, J. P. T. 2012. Sweetpotato viruses: 15 years of progress on understanding and managing complex diseases. Plant Dis. 96:168-185.

Gibson, R. W., Mpembe, I., Alicai, T., Carey, E. E., Mwanga, R. O. M., Seal, S. E. and Vetten, H. J. 1998. Symptoms, aetiology and serological analysis of sweet potato virus disease in Uganda. Plant Pathol. 47:95-102.

Gutierrez, D. L., Fuentes, S. and Salazar, L. F. 2003. Sweet potato virus disease (SPVD): Distribution, incidence, and effect on sweet potato yield in Peru. Plant Dis. 87:297-302.

Ha, C., Revill, P., Harding, R. M., Vu, M. and Dale, J. L. 2008. Identification and sequence analysis of potyviruses infecting crops in Vietnam. Arch. Virol. 153:45-60.

Hahn, S. K. 1979. Effect of virus (SPDV) on growth and yield of sweet potato. Exp. Agric. 15:253-256.

Karyeija, R. F., Kreuze, J. F., Gibson, R. W. and Valkonen, J. P. T. 2000. Synergistic interactions of a potyvirus and a phloemlimited crinivirus in sweetpotato cultivars. Virology 269:2636.

Kreuze, J. F., Karyeija, R. F., Gibson, R. W. and Valkonen, J. P. T. 2000. Comparisons of coat protein gene sequences show that East African isolates of Sweet potato feathery mottle virus form a genetically distinct group. Arch. Virol. 145:567-574.

Kreuze, J. F., Perez, A., Untiveros, M., Quispe, D., Fuentes, S., Barker, I. and Simon, R. 2009. Complete viral genome sequence and discovery of novel viruses by deep sequencing of small RNAs: A generic method for discovery and sequencing of viruses. Virology 388:1-7.

Kwak, H. R., Kim, M. K., Jung, M. N., Lee, S. H., Park, J. W., Kim, K. H. and Choi, H. S. 2006. Virus diseases incidences of sweet potato in Korea. Plant Pathol. J. 22:239-247.

Kwak, H. R., Kim, M. K., Jung, M. N., Lee, S. H., Park, J. W., Kim, K. H. Ko, S. J. and Choi H. S. 2007. Genetic diversity of Sweet potato feathery mottle virus from sweet potatoes in Korea. Plant Pathol. J. 23:13-21.

Kwak, H. R., Kim, M. K., Nam, M., Kim, J. S., Kim, K. H., Cha, B. and Choi, H. S. 2013. Genetic compositions of Broad bean wilt virus 2 infecting red pepper in Korea. Plant Pathol. J. 29:274-284

Li. F., Xu, D., Abad, J. and Li, R. 2012a. Phyogenetic relationships of closely related potyviruses infecting sweet potato determined by genomic characterization of Sweet potato virus $G$ and Sweet potato virus 2. Virus Genes 45:118-125.

Li, F., Zuo, R., Abad, J., Xu, D., Bao, G. and Li, R. 2012b. Simultaneous detection and differentiation of four closely related sweet potato potyviruses by a multiplex one-step RT-PCR. Journal of Virological Methods 186:161-166
Mukasa, S. B., Rubaihayo, P. R. and Valkonen, J. P. T. 2003. Sequence variability within the 3'-proximal part of the Sweet potato mild mottle virus genome. Arch. Virol. 148:487-496.

Mukasa, S. B., Rubaihayo, P. R. and Valkonen, J. P. T. 2006. Interactions between a crinivirus, an ipomovirus and a potyvirus in coinfected sweetpotato plants. Plant Pathol. 55:458-467.

Opiyo, S., Ateka, E., Owuor, P., Manguro, L. and Miano, D. 2010. Development of a multiplex PCR technique for simultaneous detection of Sweet potato feathery mottle virus and Sweet potato chlorotic stunt virus. Journal of Plant Pathology 92:363-366

Qin, Y., Zhang, Z., Qiao, Q., Zhang, D., Tian, Y. and Wang, Y. 2013. Molecular variability of Sweet potato chlorotic stunt virus (SPCSV) and five potyviruses infecting sweet potato in China. Arch Virol. 158:491-495.

Rännäli, M., Czekaj, V., Jones R. A. C., Fletcher, J. D., Davis, R. I., Mu, L. and Valkonen, J. P. T. 2009. Molecular characterization of Sweet potato feathery mottle virus (SPFMV) isolates from Easter Island, French Polynesia, New Zealand and southern Africa. Plant Dis. 93:933-939.

Rodriguez Pardina, P. E., Bejerman, N., Luque, A. V. and Di Feo, L. 2012. Complete nucleotide sequence of an Argentinean isolate of Sweet potato virus G. Virus Genes 45:593-595.

Rossel, H. W. and Thottappilly, G. 1988. Complex virus diseases of sweet potato. In: Exploration, maintenance, and utilization of sweet potato genetic resources. Report of 1st Sweet Potato Planning Conference. 1987. International Potato Centre, Lima, Peru.

Rukarwa, R. J., Mashingaidze, A. B., Kyamanywa, S. and Mukasa, S. B. 2010. Detection and elimination of sweetpotato viruses. Afr. Crop Sci. J. 18:223-233.

Untiveros, M., Fuentes, S. and Salazar, L. F. 2007. Synergistic interaction of Sweet potato chlorotic stunt virus (Crinivirus) with carla-, cucumo-, ipomo-, and potyviruses infecting sweet potato. Plant Dis. 91:669-676.

Untiveros, M., Fuentes, S. and Kreuze, J. 2008. Molecular variability of sweet potato feathery mottle virus and other potyviruses infecting sweet potato in Peru. Arch. Virol. 153:473483.

Wang, M., Abad, J., Fuentes, S. and Li, R. 2013. Complete genome sequence of the original Taiwanese isolate of Sweet potato latent virus and its relationship to other potyviruses infecting sweet potato. Arch. Virol. 158:2189-2192.

Yun, W. S., Lee, Y. H. and Kim, K. H. 2002. First report of Sweet potato latent virus and Sweet potato chlorotic stunt virus isolated from sweet potato in Korea. Plant Pathol. J. 18:126129. 